\title{
DYNAMISM AND DEVELOPMENT: ECONOMIC GROWTH AND SOCIAL CHANGE IN POST-MAO CHINA
}

\section{LINDA WONG AND KA-HO MOK}

As China enters into the seventeenth year of reform, the success of its economic policies has been widely recognised. This paper examines the theme of dynamism and development by examining the link between economic growth and social change. The first half of the paper discusses the social effects of rapid growth. In the second half, an area example, that of the Pearl River Delta, is offered to illustrate some of the growth-related issues and the relationship with social development, with particular reference to the question whether China has become a "risk society" resulting from "rush-to" modernisation. The authors argue that rapid economic growth may not bring about social progress, but rather, create ineffective social management if development is not conceived from a holistic and comprehensive perspective. Therefore, we must examine social development and economic growth as interrelated phenomena, paying particular attention to complementarity in public policy, social development, and market-related economic intervention.

\section{Introduction}

Sociologists of development have recently proposed the idea of "risk society" to describe the pathological consequences of "rushto"modernisation. "Rush-to" modernisation refers to a process whereby the principal goals of development are enhanced productivity and rapid economic growth pursued at the expense of the development of other aspects. ${ }^{1}$ To borrow Herbert Marcuse's phrase "one-dimensional man", "rush-to" modernisation is tantamount to "one-dimen- 
sional development."2 As a corollary, such a "rush-to" modernisation process produces exceedingly fast growth rates in the economic realm but the distributional consequences of growth are generally ignored. Not surprisingly, multiple kinds of social problems emerge, including urban/rural disparity, widening income gap, gallopıng inflation, and other socio-economic-political crises. ${ }^{3}$ Fundamentally concerned with immediate tangible results, people pay little regard to the possible negative repercussions that such development strategies and plans would bring to society. This, in the extreme case, leads to the point where people neither care for the future nor bear responsibilities for what they have done. It is against such a context that Beck proposes the idea of "risk society":

Every society has experienced dangers. But risk is the function of a new order. It is not national, but global. It is rather intimately connected with an administrative and technical decision making process. Risks presuppose decision. These decisions were previously undertaken with fixed norms of calculability, connecting means and ends or causes and effects. These norms are precisely what risk society has rendered invalid. ${ }^{4}$

In this regard, risk society is the product of incomprehensive development plan adopted by irresponsible and short-sighted government, the disaster of which is interwoven with cultural and institutional realities. 5 Without conceiving development from a holistic and comprehensive perspective, people thus suffer from ineffective social management.

Similarly, Midgley contrasts "development" and "distorted development" by arguing that economic growth may not bring real social progress, let alone realising the goal of achieving social welfare for all. Differing from residualist-institutionalist approaches to social welfare in that they are both subsidiary to the economy, the social development approach which Midgley proposes tries to transcend the residualist-institutionalist debate by emphasising the complicated linkage between economic growth and social welfare, thus highlighting the importance of social interventions which are compatible with 
economic development objectives. ${ }^{6}$ According to Midgley, the phenomenon of "distorted development" is rather common in many parts of the world because economic development has not been accompanied by an attendant degree of social progress. Not surprisingly, rapid economic modernisation has resulted in regional disparity, highly skewed income distribution, poverty, deprivation, low health status, insufficient housing, unemployment, oppression of women, and a variety of social problems. Central to these social crises is not "the absence of economic development but rather a failure to harmonize economic and social development objectives, and to ensure that the benefits of economic progress reach the population as a whole." 7

Upon a deeper reflection on the essence of development, sociologists and economists have begun to accept the fact that economic growth is only one dimension of development and that attention must be turned to whether people really enjoy substantial improvement in life quality. ${ }^{8}$ In the early $1990 \mathrm{~s}$, the acceptance of the notion of "sustainable development" and the publication of a series of reports on "human development" by the United Nations are highly indicative of a renewed international concern for harmonising social policies with measures designed to promote economic development. Taking a step further, the United Nations convened the World Summit on Social Development in 1995. After a period of neglect, social welfare is again becoming an important issue for international discussion, thus showing people's heightened awareness of the need for sustainable development. In essence, social development is concerned with assessing whether economic prosperity has achieved social purposes which are principally concerned with human well-being. ${ }^{9}$ Hence, social development embraces a large number of concerns. These are bound up with economic change and development, in the process of which the state should take active steps to ensure complementary policy provisions to resolve problems or crises resulting from "rush-to" industrialisation. Therefore, we must examine social development and economic growth as interrelated phenomena, paying particular attention to complementarity in public policy, social development, and marketrelated economic intervention.

As China enters into the seventeenth year of reform, the success of its economic policies has been widely recognised. This paper exam- 
ines the theme of dynamism and development by examining the link between economic growth and social change. The first half of the paper discusses the social effects of rapid growth. In the second half of the paper, an area example, that of the Pearl River Delta, is offered to illustrate some of the growth-related issues and the relationship with social development, with particular reference to the question whether China has become a "risk society" resulting from "rush-to" modernisation.

\section{Economic Reforms and the Emergence of a Market-Oriented Society}

\section{Rapid Economic Growth}

In the post-Mao era, the Chinese leadership has made great strides in maximising economic growth to improve the living conditions of the people. Promoting economic advancements by opening to the world economy through an export-oriented strategy and simultaneously developing a market economy, the Chinese Communist Party (CCP) has accomplished its goal to transform China into a region which bears the characteristics of a middle-income country in terms of social and economic indicators. ${ }^{10} \mathrm{Her}$ remarkable economic performance can be gleaned from various indices. In 1978, China's Gross National Product (GNP) was only 362.4 billion yuan. In 1994 , it jumped to $4,491.8$ billion yuan whereas the per capita GNP stood at 3,679 yuan, some ten times over that in 1978.11 In terms of purchasing power parity, the World Bank estimates that per capita GDP swelled from US $\$ 1,000$ in 1978 to US\$2,510 in 1994..$^{12}$ Between 1978 and 1994, China's import and export trade increased from US $\$ 20.6$ billion to US $\$ 236.7$ billion, at 16.5 per cent per year. ${ }^{13}$ As far as consumption is concerned, there has also been remarkable improvement for urban residents and people living in the rural areas. Over the same period, per capita consumption for the former increased from 405 yuan to 3,956 yuan; that for the latter rose from 138 yuan to 1,087 yuan. ${ }^{14}$ Savings deposit of rural and urban residents likewise increased from 21.1 billion yuan to 2151.9 billion yuan. ${ }^{15}$ Some 200 million people were also lifted from absolute poverty. ${ }^{16}$ The latest economic forecasts are very favourable, with all 
major economic indices showing a consistent trend of economic development and increased productivity while the rate of inflation has been held in check. ${ }^{17}$

\section{The Evolution of Physical and Symbolic Marketing System}

The economic indicators reveal that China has undergone substained economic development. At the same time, they are also suggestive of the emergence of physical and symbolic marketing systems. According to Sklair, physical marketing system is defined as the extent and types of retail and other outlets for consumer goods and services. Meanwhile symbolic marketing system refers to the extent and types of marketing, principally but not exclusively advertising and mass media, directed towards consumers. ${ }^{18}$

The policy of opening up that started in the late 1970s has had considerable impact on the formation of a physical marketing system in China. ${ }^{19}$ The most important changes in the distribution of goods and services have been the mushrooming of rural markets particularly in the suburbs of cities, the huge increase in the number of individuals and families that have become traders, the growing demand for better quality products, and the growth of multiple sources of goods for their customers. People's enhanced consumption ability pointedly reveals that a dynamic market has taken root in China. From the late 1970 s onwards there has been a pure quantitative expansion in the purchases of the "Big Four" (bicycles, sewing machines, watches, and radios) as the accumulated excess demand of the pre-reform years found an outlet. More households, especially in the urban areas, began to purchase new durable goods like low-priced record players and black and white television sets. Other items, such as refrigerators and washing machines, might cost between five and eight times an average worker's monthly salary. Nevertheless, the "Big Four", the most commonly aspired-to consumer items of the 1970s, have been replaced in the 1980 s by refrigerators, washing machines, colour television sets, and other expensive, perhaps "luxury", items. ${ }^{20}$ In recent years, people's spending on food has been reduced while expenditure on more consumer durables has increased, indicating a real enrichment of people's living standards, particularly in the material do- 
main. ${ }^{21}$ Such a rapid growth in consumption and all-embracing transformation of lifestyles confirm the formation of a physical marketing system in the mainland.

In the Deng era, the south-eastern coast and most Chinese cities have been opened up for foreign investment and trade. By the late 1980s, millions of Chinese have found work in export-processing enterprises and millions more have started their own businesses. ${ }^{22}$ In 1994, township and village enterprises were employing 120.2 million workers. During this period, the urban sector has been booming. At the end of 1994,3.3 million persons were employed by private businesses, while 12.3 million worked in the individual economy. In 1978, only 150,000 persons were self-employed. ${ }^{23}$ In addition to the registered units, there are also millions of unregistered small family enterprises, the development of which not only facilities the formation of an "entrepreneurial class" but also increases the size of the private sector in an exceedingly rapid way. ${ }^{24}$

Undoubtedly, the expansion of foreign investment further supplies the impetus for the flourishing of a market economy in China. Since 1983, the inflow of foreign capital to China has grown twentyeight times. With the translation of Chinese cultural values into entrepreneurial acts, a great deal of economic dynamism is generated, in particular by overseas Chinese businessmen. ${ }^{25}$ This influx of foreign capital has given rise to a vast number of private and jointventure enterprises in the mainland. The growth in the number of firms with foreign financial sources has been extremely rapid, increasing from 1,392 in $1983,15,997$ in 1988 , to 130,000 in 1992, producing about 25 per cent of China's export and 9 per cent of the gross value of industrial output. ${ }^{26}$ In 1994, foreign investments in China amounted to US $\$ 33.7$ billion, against a total fixed asset investment of 1,592.6 billion yuan. ${ }^{27}$ Obviously, continual foreign investments have driven China's economy forward, making the country more economically dynamic and productive.

Against a new market setting, more people are doing business and entering the commercial field, especially after the official endorsement of the socialist market economy in 1992. A wave of "jumping into the sea" (going into business) evolved after Deng Xiaoping's tour to the south during the Spring Festival of that year. From a base of 
150,000 persons in 1978 , the number of urban and rural individual industrialists, businessmen, private enterprise owners, and self-employed persons expanded to more than 44.68 million people in $1994 .{ }^{28}$ In addition to these registered private entreprenuers, university students, intellectuals, local leaders, and ordinary workers have also engaged in legal but unregistered and untaxed economic activities. ${ }^{29}$ Furthermore, urban collectives, village enterprises, rural township, and firms with foreign investments have assumed a more important role in China's economic sphere, accounting for a gross value of industrial output from 20 per cent in 1979 to 51 per cent in 1992. By 1993, the non-state sector contributed 70 per cent of China's GDP. ${ }^{30}$ A recent estimate further suggests that over 95 per cent of consumer goods are now circulated in the market, while only 20 categories of production materials are under planned allocation. ${ }^{31}$ In view of such a development, there has been wide agreement that the engine of China's economic growth has been the non-state sector. ${ }^{32}$

Along with the emergence of a physical marketing system, a symbolic marketing system has been developing in the post-Mao era. From the mid-1960s until the late 1970 s, there was practically no product-advertising in China. Anderson documents the rebirth of the advertising industry in the People's Republic of China since the adoption of the open door policy. ${ }^{33}$ In order to promote their products, the transnational corporations have created new consumption needs by means of advertisement. Stross observes that advertising in China has flourished rapidly, growing from 10 agencies (state-run) in 1980 to 7,000 (mostly non-state) in $1988 .{ }^{34}$ These observations indicate that a consumer revolution has occurred in the Deng era, giving rise to a symbolic marketing system. The popularity of advertisements has considerably influenced people's consumption as documented by many studies. ${ }^{35}$ For instance, a study on consumption and consumer behaviour in the Pearl River Delta reports a growing consciousness of consumerism among citizens in the area. ${ }^{36}$ Furthermore, the tremendously fast increase in people's consumption, together with an allembracing transformation of people's lifestyles seem to indicate that consumerism may emerge as a dominant culture-ideology shared by the residents living in mainland China. ${ }^{37} \mathrm{All}$ in all, economic reforms have not only given China's market economy a new life, but have also significantly altered the social structure. 


\section{Economic Prosperity and Changes in Social Configuration and Social Stratification}

\section{Increased Opportunities for Social Mobility}

As discussed earlier, the take-off of the market economy and the continuous inflow of foreign capital have greatly improved people's living standards and improved their life quality. More importantly, economic modernisation has provided Chinese citizens with far more opportunities for social mobility. Unlike during the Mao era when social mobility was constrained because people were allocated to different danweis (work units) without their consent or any chance of job transfer, ${ }^{38}$ people in the post-Mao period have more job choices, especially when a relatively free labour market has emerged since the mid-1980s. The booming of private and joint-venture enterprises has increased people's job mobility, a condition which would eventually change the country's occupational structure. ${ }^{39}$ As some statistics show, 90 per cent of job transferees have obtained their posts in fcreign-funded enterprises, rural and township enterprises, and private enterprises, which offer higher renumeration and better welfare benefits. ${ }^{40}$ Besides, the mushrooming of rural companies and the increasing opportunities for peasants to change occupations are remarkable. In 1993, more than 100 million out of 900 million people with registered residence in the countryside moved to market towns and cities, believing that better chances and job opportunities were available there. ${ }^{41}$ These migrants have supplied rural industries with abundant labour force, producing about 38 per cent of the gross value of industrial output in 1993.42 Increased opportunities for social mobility suggests a lessening of state control over people's movement, work, and lifestyle.

\section{Rise of the New Rich and Renegotiation of Power Relations}

Real income increases have not only enriched the general public but have also enabled them to renegotiate a new relationship with the state. In 1994, the per capita income available for living expenses for urban residents was 3,179 yuan and 1,221 yuan for rural dwellers, represent- 
ing an increase of 35 per cent and 30 per cent, respectively, over the last year. ${ }^{43}$ At the end of 1995 , a report by Workers' Daily estimated that in urban areas 6 per cent of urban households could be classified as "high-income" households (with an annual income between 30,000 and 100,000 yuan and assets worth 87,000 yuan) and 3 per cent could be classified as "rich" households (annual income over 100,000 yuan and assets worth 400,000 yuan). ${ }^{44}$ There are also a million millionaires in the country. ${ }^{45}$ At the same time, people's savings deposited into banks also expanded. In 1994, the savings of urban and rural households amounted to 2151.9 billion yuan; in 1978 , it was only 21.1 billion yuan. ${ }^{46}$ These figures confirm that Chinese people have accumulated more wealth and are earning much higher incomes. Against this background, the rise of a new middle class is made possible. As sociologists believe, accumulation of wealth can lead to a demand for power redistribution. ${ }^{47}$ Now that Chinese people are growing richer and are no longer dependent on the state for everything, they can have more control over their lives, particularly when they now enjoy private ownership. Instead of being stuck with a danwei for life, now Chinese people have the choice of "exit." 48 Having regained economic independence, Chinese residents have more freedom to relocate themselves, to exchange products, and to determine their own lifestyles. ${ }^{49}$ Hence decreased dependence on the state has empowered people, leaving them with more alternatives of life choice. As Lin Jing observes, "[people] still have to deal with the government, but it is only when they pay taxes or are checked for environmental damages and so on." 50 In this regard, the extent of the reach of the omnipresent state into people's ordinary life is greatly reduced.

The rise of the new rich has given China's political scene a new shape. These affluent businessmen and entrepreneurs exert influence over both the economic realm and the political sphere, especially when the local leaders are in need of entrepreneurs' financial support to initiate more reforms and developmental projects. Thus an "alliance" between the two parties is formed, the rise of which has affected the power relations between the state and the "new elites." 51 Yan describes such power relations as "a dual structure of social-economic stratification that emerged in the countryside characterized by the coexistence of bureaucratic rank order with a market-based economic 
class order." 52 The formation of this "capital-bureaucrat" class may eventually alter the existing social structure. In short, the growing importance of these "elites" and the flooding of rural labourers into the cities are the most visible signs of the restructuring of Chinese society, depicting also a structural change in social stratification and in the system of social status. ${ }^{53}$

\section{Emergence of Relatively Autonomous Social Associations}

In addition to the breakdown of the conventional, rigid, and closed class system in the past, post-Mao Chinese society is also characterised by the emergence of voluntarily organised and autonomous social associations and professional organisations. A large-scale survey conducted among fifty Beijing universities in 1986 revealed a steady growth of autonomous groups on the campuses. For example, from 1983 to 1986, there was a 58 per cent increase in the growth of associations, with participation in such activities growing from 13,000 to $40,000.54$ There are essentially five types of social associations in China, namely, special interest groups like trade associations; corporations set up by provincial or local governments; professional societies; promotional groups such as the Chinese Society for Sports Science; and finally a large motley collection of learned societies, associations, foundations, research institutes, and clubs. ${ }^{55}$ As Liu observes, "their [the voluntary organisations] flourishing since 1980 is yet another indication of the resurgence of natural man and community in mainland China. The associations were a result of people freely communicating and transacting with one another, and they represented the mainland Chinese people's rejection of the Communist Party's centrally mobilized and socially segregated society." 56 Even though Chinese people's associational life was once restricted after the June-Fourth Incident of 1989, the rise of a market economy has unquestionably encouraged new forms of social engagement. The relaxed socio-political environment has facilitated the proliferation of karaoke bars, dance halls, and private restaurants, the development of which has given Chinese citizens far more physical and social mobility and encouraged more social interaction beyond their work units. ${ }^{57}$ In spite of the fact that politically-motivated organisations were 
repressed in the post-June-Fourth era, social organisations of various kinds such as professional bodies, interest groups, trade and cultural associations have continued to flourish. ${ }^{58}$ Against such a context, Sullivan suggests that the assertion of self-rule or independence from the omnipresent state has become an unprecedented expression of Chinese society. ${ }^{59}$ Putting the above-mentioned observations together, it suffices to argue that post-Mao China has become more pluralistic in outlook. In the process, Chinese citizens have attempted to change the conventional order and to renegotiate a new private/ public distinction. ${ }^{60}$

\section{Economic Prosperity and Changes in the Socio-Cultural Realm}

\section{Plurality of Values and Fundamental Mentality Change}

In addition to causing structural changes in post-Mao society, the economic reforms have gone all the way to altering people's value orientations. As the market economy develops, more people living in China have internalised a new cluster of values, notably the acceptance of individual striving and market competition. As a result, notions like personal interests, material incentives, differential rewards, economic efficiency, and market distribution are in ascendance. ${ }^{61}$ In order to survive or get ahead, many people aspire to obtain wealth through individual struggle. Thus, a practical philosophy "either rich or poor, you are on your own" kind of mentality has prevailed. Such a shift in value from socialist-idealism to marketorientation has far-reaching significance for China's socio-political development. ${ }^{62}$

Undeniably, the "open door" policy has exposed Chinese people to the outside world, creating also a comparatively relaxed sociocultural environment. After the death of Mao, the state has failed to create a compelling ideology to engage the trust of the people and thus a self-legitimation crisis was reported. ${ }^{63}$ At the same time, Western ideas appear to have made deep inroads in the political thought of Chinese people, as suggested by a number of studies. For example, Rosen observed that "a broad spectrum of the population seemed to agree that Western thought could be beneficial to China." 64 A national 
survey of Chinese political culture conducted in 1989 by an independent group of young and middle-aged Beijing political scientists reported that not only the highly educated and urbanised segment of the population but also party and communist youth league members adhered to Western ideas regarding assertion of individual choice. ${ }^{65}$ Another survey also found support for such Western values as freedom of expression and freedom of speech. ${ }^{66}$ Even after the crackdown of the pro-democracy movement in 1989, a wide range of survey data intimated that many students still admired Western democracy and supported capitalism. ${ }^{67}$ Unlike Zheng's argument that Chinese people in the mid-1980s were still ignorant of and ambivalent towards the ideas of democracy, rights, and citizenship, ${ }^{68}$ Chinese residents are now more aware of the importance of individual rights and democracy. Different opinion surveys report the rise of ind ividualism and the weakening of collectivism. There is also a greater reluctance to pass judgement on other people's "private matter." When asked: "What do you think about people reading pornographic magazines?", many respondents considered it a private and personal matter; only a small proportion regarded it as detrimental to morality and society. There was also wide endorsement for free choice in religion, thinking, and life goals, with most believing that the state should not attempt to interfere with the private life of citizens. ${ }^{69}$

With opportunities of listening to the Voice of America (VOA) and the British Broadcasting Corporation (BBC), and reading Western publications, Chinese people have become more dissatisfied with the present situation, culminating in outbursts that are critical of the government. This may explain why many Beijing residents supported the slogans of democracy and showed sympathy to students' demonstrations for freedom, democracy, science, and human rights during the Tiananmen Square Incident in $1989 .{ }^{70}$ More importantly, people living in China have a habitual change after the 1989 student demonstrations. Before the crackdown, most Chinese citizens used to listen to the news and messages broadcasted by the CCP early in morning; nowadays, few bother to tune in to such "official announcement."71 Additionally, scholars have openly initiated the discourse on "civil society" from the mid-1980s onwards. No matter how divergent their interpretations and views on civil society are, Chinese intellectuals' 
conceptualisation of civil society has formative influence on China's social and political life. This might in future alter the nature and functions of existing institutions. ${ }^{72}$ Divorcing themselves from the Marxist approach, Chinese intellectuals have become more aware of the negative consequences of "mass society" and more critical of the ostensible incoherence of the dominant official ideology. Such awakening has also cultivated the ground for a plurality of thought in postMao China. ${ }^{73}$ All this suggests that Chinese people have a fundamental mentality change, in that they are finding pluralistic value orientations more acceptable. These changes take place not only in people's thoughts but also in their behaviour, as revealed by their critical attitude towards the socialist system and the domination of the CCP. ${ }^{74}$

\section{Intensified Income Disparity and Social Inequality}

There is no doubt that China has experienced exceedingly rapid economic growth and that the people in general have enjoyed enhanced socio-economic opportunities after the initiation of economic reform. What is also true is that there has been an increase in income disparity and social inequality, which are concomitant consequences of fast growth. As a result, some sectors of the population who are unable to keep pace with rapid changes have lagged behind others. Therefore, it is not surprising to hear people's complaints that years of economic reforms have produced a number of privileged groups. The CCP has stated publicly its intention of letting some people get rich first, a process which gradually widens the gap between the rich and the poor and gives rise to ill-feelings and jealousy among various provinces and localities. ${ }^{75}$ Popular dissatisfaction with the income gap is immediately apparent in popular rhymes which denounce the inequality among different sectors. One such rhyme is particularly effective in summing up the popular mood: "The reform has made peddlers and those who live on the coast rich, but has impoverished and deceived those who live on salaries ... It has allowed young people to be promoted, enriched peasants, and benefited senior cadres, while causing workers to be more strictly controlled."76

Urban workers, intellectuals, and others on fixed salaries, having encountered such an income disparity, have responded sharply. The 
preferential treatment granted to the coastal areas and special economic zones has created millionaires while typical middle school teachers and college professors remain underpaid, at levels worse than those of the 1950s. For instance, the salaries of senior intellectuals (including professors and researchers) dropped from a range of 345149 yuan in 1950 s to $225-122$ yuan in the 1980 s. Qian Jiaju, a prominent Chinese economist, argues that the real wage of the intellectuals is only one-tenth of that in the $1930 \mathrm{~s} ;{ }^{77}$ nor has there been any improvement until recent years. ${ }^{78}$

The income differential between factory workers and intellectuals is even wider when seniority is considered. Among all age groups, middle-aged intellectuals are least advantaged when workloads and incomes are compared. Similarly, the income gap between manual and mental workers is very wide because households running industrial and commercial businesses have enjoyed enormous increases in their earnings. Thus the saying has emerged that "the one who writes books is inferior to those who sell them" and "those who teach students to play the piano are inferior to those who move pianos." What is even worse, "those using their brains are inferior to those using razors, and those who design atomic bombs are inferior to those who sell salted eggs." 79 Income gaps occur not only across occupations but also within the same occupation, for instance, labourers working in private and non-state enterprises. Not surprisingly, pay disparities between different occupational groups increase workers' grivances. Witnessing many business people (such as the getihu) earning a huge amount of money makes workers even angrier.

In the second half of the paper, we present a case study to illustrate the complex relationship between economic growth and social change.The example chosen is the Pearl River Delta, one of the fastest growing and most prosperous areas in China. One of the authors, Linda Wong, visited the area in 1988 and again in 1993. The data reported below originated from these field trips. ${ }^{80}$ 


\section{Case Study of the Pearl River Delta}

\section{Rapid Economic Growth}

The Pearl River Delta Open Economic Area (PRDOEA) covers an area of 41,596 square metres. In 1993, it had a population of 20.56 million. The GDP of the PRDOEA was 226.5 billion yuan and the GNP was 175.8 billion yuan. Between 1980 and 1993, the GDP and GNP grew a staggering 7.1 and 6.5 times, respectively, with annual growth rates of 17.5 per cent and 16.8 per cent. ${ }^{81}$ Such rates surpass those of the Four Little Dragons (Hong Kong, Singapore, Taiwan, and South Korea) and rank among the highest in "ne world. Most of this growth can be accounted for by industrial levelopment. Between 1980 and 1993, the annual increase in induc: alal output was 21.7 per cent. In money terms, the value of indusurial production for 1993 was 360.1 billion yuan, which was 11.8 times over 1980 . Thus with only 31.2 per cent of Guangdong's population and 23.4 per cent of its land area, the region accounted for 70.2 per cent of the province's GDP. ${ }^{82}$ To the outside world, the delta area is synonymous with economic success, high incomes, and good living. At the same time, however, rapid growth has resulted in inequality and rising social polarisation. Alongside the opulent lifestyle of the rich and comfortable standards of living for the general population, one can witness grave problems afflicting migrant workers and the poor. Also visible are such problems as prostitution, gambling, drug abuse, and crime. The overall scenario is thus a society with a galloping economy ("rush-to" modernisation) but inadequate attempts at managing the social effects of economic change. The area can easily become a "risk society" if the present state of affairs deteriorates.

In the delta area, the cities of Dongguan, Nanhai, Shunde, and Zhongshan, touted as the Four Little Tigers of the Pearl River Delta, are particularly outstanding. All four started off as rural counties and have been upgraded to city status in the late 1980s and early 1990s.

The prosperity of the four delta counties is not a new phenomenon. Before 1949, their general affluence was well known. Situated close to Guangzhou and Hong Kong, they have the advantages of excellent transport, fertile soil, good climate, advanced agriculture, and skilful 
handicraft. Above all, they have had a long history of trade links with southern China and abroad: 70 per cent of overseas Chinese originated from here. After 1949, closure of the border and the pursuit of an isolationist policy resulted in its ties with the outside being severed.

Considered a frontier region by Beijing, the delta area, and Guangdong as a whole, was also denied much-needed state investment. For thirty years, the local economy stagnated until the reform programme rekindled the flames of rebirth. The del ta counties grasped the opportunities provided by the new flexible policies and exploited them to the full. Links with the outside world, especially with Hong Kong, were quickly revived and vast sums of money were spent to build roads, bridges, and physical infrastructure. Much of the money was raised locally through levies and from outside investment. The purpose was to prepare the area for an economic take-off.

Another asset is local leadership. Unlike their seniors in provincial and municipal administrations, county leaders are recruited locally and the delta counties are firmly committed to restore growth and glory to their home base. ${ }^{83}$ Under such favourable conditions, the economy soared. In agriculture, cash crops replaced rice cultivation; aquatic products and livestock rearing also boosted rural incomes. Building, transportation, and trade boomed. Above all, rural industries provided the lion's share of local income. Since the reforms began, the number of township and village enterprises increased by 35 per cent or more per year.

The social and economic characteristics of the tigers are rather similar, as shown in Table 1. After the initiation of economic reform, their economies have experienced astounding growth. By the late 1980 s they have become highly urbanised and industrialised. Nonetheless, the four cities have followed slightly different trajectories of industrial development. Among the four, Shunde's strength lies in its large and modern township enterprises. Zhongshan has more largescale state enterprises which have been technologically upgraded. Dongguan is famous for its export-processing. Finally Nanhai prides itself on simultaneous growth on all fronts: at the municipal, district, township, village, joint household, and household levels. ${ }^{84}$ 


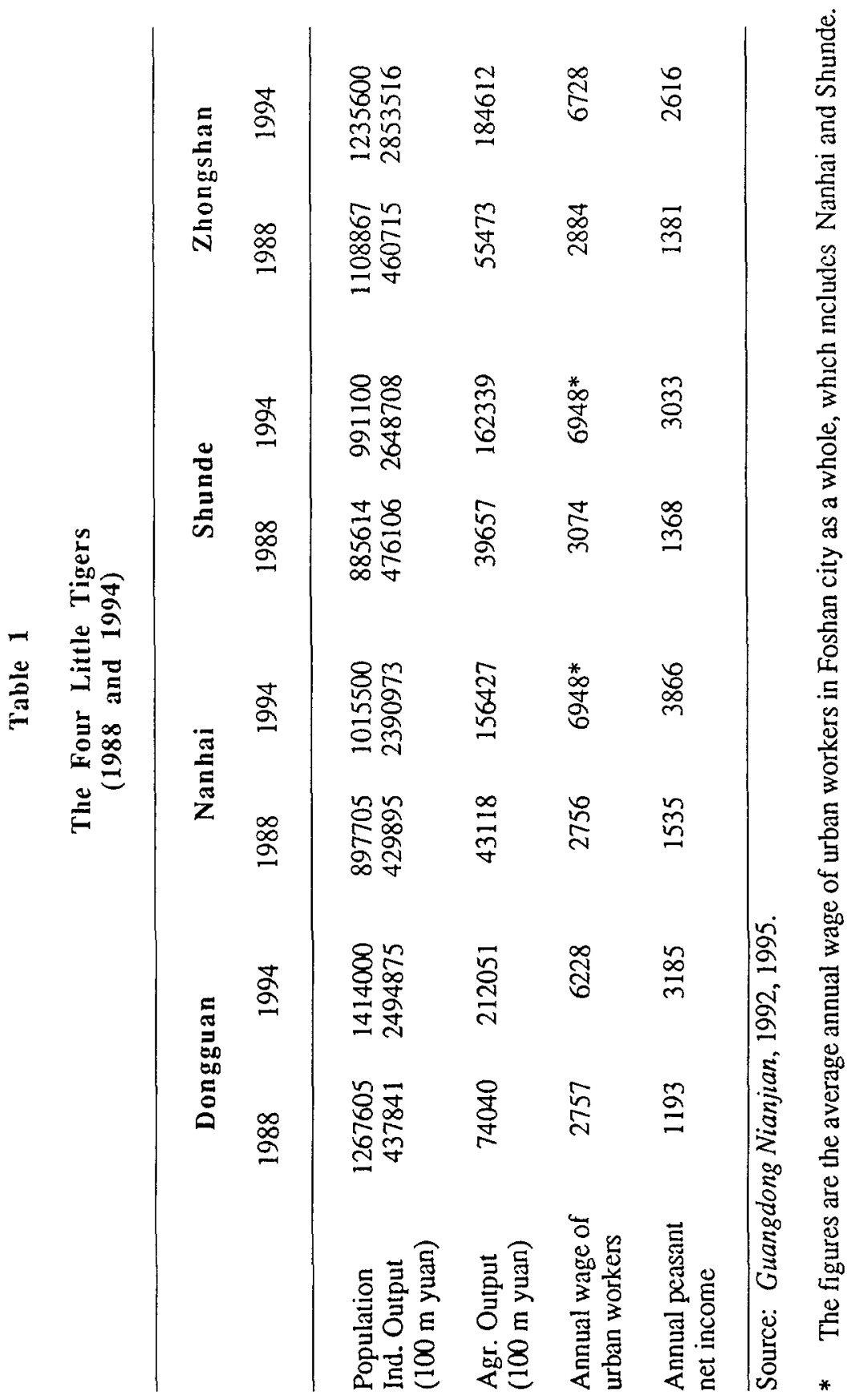


Social Stratification and Lifestyles

The general affluence of the region is obvious to any visitor. The area has good roads, water, and electricity. Imposing new factories line the major transport routes. New residences, two to three stories high, dot the countryside. Everywhere farmland and hills have been flattened for new construction. In town centres, shops are doing roaring business. Imported cars outnumber domestic vehicles. Officials, company bosses, and managers are chauffeured around in air-conditioned comfort. Among cadres, the higher the rank, the more luxurious the issue. Even low-ranking officials wear pagers; their seniors carry mobile telephones to ease communication.

Eating is big business in the four cities. The delta has had a long and distinguished culinary tradition. Indeed the best Cantonese cooking originated in such places like Shunde and Panyu in the delta. According to our field observations and interviews with local informants, business in most restaurants is brisk. Their fish tanks hold all kinds of delicacies from China and abroad. Most eateries boast about their Hong Kong chefs, serve Hong Kong-style cuisine, and charge Hong Kong prices. The big spenders are mostly firm managers, business owners, and officials. Locals say between 70-80 per cent of restaurant bills, which can easily run into thousands of yuan per table, are picked up by people with expense accounts. For truly favoured guests, a few bottles of XO and even Louis XIII fine cognac, the latter costing more than 8,000 yuan each, are offered. Such hospitality is all the more surprising since many of those signing the cheques, apart from business owners, are nominally earning around 1,000 to 2,000 yuan a month. What follows after a sumptuous meal may be karaoke singing or entertainment in one of the areas's teaming nightspots.

How much the elites earn is a secret. The area has numerous millionaires, and quite a number of them are reputed to be worth over 100 million yuan. Local officials also like to boast about the wealth in the area. Without much promting, cadres can off-handedly give the names of a number of super-wealth bosses. On the whole, underreporting of incomes is widely assumed. The rich live in lavish apartments or villas with every kind of home comfort. In Zhongshan, a city known for its building materials, people vie for the number of 
ensuite bathrooms in their residence. Opulence has also perverted social morals. According to local informants, some bosses are said to have kept mistresses. In Dongguan, such women have a penchant for fancy pet dogs. To avoid misunderstanding, families with good standing tend not to keep such animals however much they would like them. The rich are particularly eager to give their children the best education they can buy. In Guangdong, some forty expensive private schools have sprung up in recent years. ${ }^{85}$ One such school in Guangzhou asks for 300,000 yuan debenture for each pupil admitted; another school in Zhuhai demands 250,000 yuan. The response has been overwhelming. Wealthy parents in the four cities are only too happy to pay the same or more if amenities are set up locally to spare them the trouble of ferrying their children over long distances.

Average standards in the delta are more comfortable than most parts of China. Both officials and ordinary citizens say that the majority of local people live well with homes fitted out with modern electrical appliances, for which the region is famous. Indigenous residents hold the best jobs; true locals mostly work as supervisors and managers in factories and trading firms. The more enterprising operate their own business or form joint ventures, thanks to their good connections and access to resources. In the early years of the reform, there was some emigration from the area, mostly to Hong Kong. But as the local economy prospers and living standards improve, such outflows stopped. Some emigrants actually returned to start their own business, bringing with them newly learnt skills, business links, and capital earned from their stint abroad.

Native peasant households also do well. Their greatest asset is land, which can be rented out, used for factory premises, or sold. In the past, delta people were highly successful farmers but now few households work the land. If they do so at all, the heavy work is done by hired hands from outside the area. In Shunde, for example, local cadres happily pronounce that draught animals are no longer used on the land, and that even its traditional silk weaving is now exported to other hilly counties. More useful indicators of general living standards are income data. From official statistics, the four tigers are doing exceptionally well. In 1994, the average per capita income for urban residents in China was 3,179 yuan and the per capita rural net income 
was 1,221 yuan. $^{86}$ In the four cities, the figures were double the national average.

The situation of migrant workers is a lot less enviable. Reliable figures on the migrant population are not available. One estimate is 2.5 million ${ }^{87}$ but this number may have missed out many unregistered transients. The non-local population may be as high as half the registered population, with Dongguan having the most. Not surprisingly, these outsiders enjoy a lower social standing than permanent dwellers. This is not to suggest that they are a homogeneous group. At the top, there are people with prized expertise who have been recruited to work in local enterprises. These include university graduates, engineers, seasoned managers, well-qualified headmasters, school teachers, and technical personnel. The positions are advertised nationally and successful applicants are amply rewarded with high salaries, nice apartments, and generous perks. In Dongguan, Houjie Township government paid headmasters 1,800 yuan and teachers 900 yuan per month when Wong conducted field interviews there in 1993. Indeed, with the lure of good pay and benefits, the area has attracted a lot of skills and talents from all over the country, even professors, scientists, and graduates from famous universities in the north.

Ordinary labourers, who can be had by the truck load, hardly receive preferential treatment. The large supply of workers makes the local labour market very much a buyer's market. Most of the migrant workers are young, first-generation industrial workers with an agricultural background. They are mostly engaged as temporary labourers. Men tend to be concentrated in heavy construction and harzardous job while women are found mostly in rural industries and tertiary services. Monthly wages for factory workers vary according to the work they do but commonly range between 350 and 500 yuan a month. Temporary staff are usually housed in company dormitories. From first-hand observation, the living conditions in inany quarters are appalling, with row upon row of beds crowded into barrack-like rooms offering little or no privacy. Some of the better factories have common recreational areas. Most do not have such facilities.

Working conditions for many migrant labourers (min gong) leave much room for improvement. Working hours are long. Shifts of ten to twelve hours a day, six or mostly seven days a week, are quite common. ${ }^{88}$ Despite official restrictions on overtime work, forced 
overtime is routine. What is more, temporary personnel can be fired at any time. Abuse of workers' rights, for example withholding of wages, late payment, corporal punishment, sexual harrassment, and so on has been widely reported, especially in firms under foreign ownership. ${ }^{89}$ Under Chinese law, each enterprise, including foreign investment enterprise, must establish a trade union. In practice, many private and foreign-owned companies reject union activities altogether, under the connivance of local cadres too eager to lure and retain overseas capitalists. Enteprises are supposed to pay at least a minimum wage. In reality, some firms just pay the bare minimum while others do not even meet the minimum standard. Indeed, low pay, especially in the light of high inflation, has prompted a number of strikes in foreignowned enterprises in Zhuhai and elsewhere in the delta.

Equally worrying is the prevalence of industrial accidents. Some of these, like the Shenzhen Qingshuihe Dangerous Goods Depot Fire on August 5, 1993 and the Zhuli Toy Factory Fire on November 19, 1993, are particularly notorious. ${ }^{90}$ According to a government release, during January to August 1993, 11,600 workers died in industrial accidents, representing a 113 per cent increase over the same period in 1992. Among the accidents, fires accounted for the largest number. In the first ten months of 1993 , there were 28,200 factory fires resulting in 1,480 deaths, 51,340 casualties, and property losses of 845 million yuan. ${ }^{91}$

The frequency of these accidents calls for sobre reflection. First, most plant operators and local governments have been too zealous chasing after increased productivity and profits but are neglectful of industrial safety. Foreign-owned enterprises are said to be particularly culpable as they tend to be shortsighted and callous over safety matters. Second, management systems, including laws, regulations, and administration, have not kept pace with the rapid expansion of industrial development. This is especially true in the Pearl River Delta. Third, implementation of work safety and worker protection rules have been amiss. Very often, investors find it more profitable to bribe officials than to comply with the rules. In Guangdong, after scoring a dismal record of policy failures, safety regulations have been tightened. In theory, strict enforcement would eliminate the sources of most tragedies. However, in practice, lax administration has resulted 
in repeated occurences of infringements. Finally, the lack of safety consciousness among workers and their readiness to put up with unreasonable working conditions also make them easy prey to unscrupulous bosses and managers. Their lack of power and organisation, as well as inadequate trade union representation, means that labour grievances are not heeded by local officials. In fact, some cadres are not above breaking the laws themselves as government departments "jump into the sea." A case in point is the Qingshuihe explosion when the public security bureau, which is responsible for fire prevention and fire fighting, is one of the owners of the dangerous goods depot which failed to install proper safety precautions.

Indeed the lack of protection or even flagrant exploitation of migrant workers is one of the blackspots in the area's economic miracle. Min gong are generally regarded as dispensable people. They are tolerated only because they are believed to be useful. As soon as their utility vanishes, they will not be welcome by the local community. Annually, the delta area churns over the pool of outside labour supply. Older workers do not have their contracts renewed when their dexterity falls and new recruits are engaged to take their place.

Despite the area's wealth, poverty is far from extinct. Civil affairs officials readily admit to the presence of poor people in the midst of affluence. Most of the poor are found in the hilly terrain where transport is more difficult. As far as individual households are concerned, the major reasons for financial hardship include sickness, disabilities, and death in the family. People with low levels of intelligence also do badly as they fail to possess adequate skills for employment. Those who have no family, no ability to work, or no means of livelihood (the "three nos") are at the bottom of the pile. Yet, the four cities have no official poverty line.

For the urban poor, the average relief rate for a single person in 1993 was 120 yuan a month, which was one-quarter to one-third of the local average wage. For destitute peasants, assistance varied widely across localities. The more common rate was between 500 and 600 yuan per person per year, or 40 and 50 yuan a month in 1993. Government departments do not always have accurate information about the needy. Three reasons contribute to this. First, rural relief is funded by villages and towns, not by the government whose intervention is resisted by local communities. Second, data collection is not 
conducted on a regular basis. Third, welfare assistance has not been revised to keep pace with improved living standards and inflation. In private, welfare cadres complain about their lack of clout in the municipal government. Like their charges, they are sometimes treated as second-line supplicants and are shunned by top leaders for their propensity to ask for more money for the poor.

From the field surveys conducted in 1988 and 1993, the number of aged persons eligible for the "five guarantees" (food, clothing, housing, health care, and burial) in the sample cities has either remained stable or actually decreased, as shown in Table 2 . There are three possible explanations for this phenomenon: first, there may be fewer destitute homeless elderly. Second, it is conceivable that the authorities have not kept accurate statistics. Third, local communities have not allowed more needy persons to be supported at public expense.

Table 2

Old Age Support in the Four Tigers

1988

1993

Number of Five Guarantee Persons

Dongguan

Nanhai

Shunde

Zhongshan

Number of Aged Homes (and Residents)

\section{Dongguan \\ Nanhai \\ Shunde \\ Zhongshan}

Maintenance Standard for Residents (yuan per person per month)

Dongguan

Nanhai

Shunde

Zhongshan
1995

2085

2002

2456

1949

NA

1795

2466

22 (390)

$16(399)$

8 (NA)

13 (340)

$29(900+)$

18 (554)

13 (190)

Source: 1988 and 1993 field interviews. 
Local agencies are either reluctant or unable to suggest which of these are more relevant. It is however not unreasonable to assume that the second situation is the most likely.

Table 2 also shows that, with the exception of Dongguan, the other three tigers have expanded facilities and taken care of more elderly indigent people; the amount of maintenance payment has also increased from about 40 yuan per person per month to between 100 to 120 yuan per person per month. Nevertheless, these sums are rather miserly when compared to average income. As of 1993, none of the cities, reputedly among the richest in the country, met the recommendation of the Ministry of Civil Affairs to set up one care facility for local old people in each township or administrative village.

Regarding support for the disabled, the four cities have substantially increased the number of welfare factories, as seen in Table 3.

Table 3

Welfare Factories in the Four Tigers

(and their disabled employees)

\begin{tabular}{lll} 
& 1988 & 1993 \\
Dongguan & $5(542)$ & $11(340)$ \\
Nanhai & $8(330)$ & $22(1100)$ \\
Shunde & $25(381)$ & $56(1600)$ \\
Zhongshan & $1(51)$ & $39(467)$ \\
\hline
\end{tabular}

Source: 1988 and 1993 field interviews.

In Dongguan and Shunde, the rise was more than double, and in Nanhai and Zhongshan the expansion was even greater. In comparison, the intake of disabled employees has been less impressive. In 1993, Dongguan actually had fewer disabled persons performing welfare production work than five years previously despite the increase of unit number. The only plausible explanation is that disabled staff have been laid off, a practice that has become more common in other places. What usually happens is that disabled employees are "retired" with a monthly allowance and their places are then filled by 
able-bodied temporary workers. Officials are reluctant to divulge the size of the temporary workforce beyond saying that their numbers fluctuate with job orders. What is known is that such workers have become the mainstay of front-line staff in these factories. Indeed the last few years have seen welfare enterprises encountering more acute competition. Such units are fighting an increasingly uphill battle to stay afloat. Replacing disabled staff by more able workers who can be summarily dismissed enables firms to cut costs. On the other hand, the government has difficulty safeguarding the jobs of the disabled since the majority of units are operated by the non-state sector. By the same token, civil affairs officials now find it harder to persuade people to start welfare production. Again, the four cities have not achieved the guideline of having one project in each township or village as stipulated by the Civil Affairs Ministry. Dongguan's record seems to be poorer than the others.

Welfare officials are acutely aware that their achievements in social welfare lag behind the region's economic success. The state of welfare assistance was paltry in 1988 and after five years of breathtaking economic growth, the welfare gap seems more pronounced than ever. Among the four tigers, Nanhai is the most determined to speed up its welfare programme. Between 1993 and 1994 its welfare department aimed to set up one home for the destitute, one welfare factory for the disabled, and one welfare fund for every village and township. The others seem less committed. However, all four cities have plans to build a children's home to cater for the increasing number of abandoned and handicapped children and a large multipurpose facility to assist the old and the needy.

What happens in welfare provisions in the four tigers parallels the welfare record of Guangdong as a whole - a significant gap between its economic ability and welfare performance. The lesson to be drawn is that affluence need not breed generosity. The will to improve the plight of the poor is as instrumental as possessing the means to do so.

\section{Social Problems}

Besides unmet needs, a number of social problems has become increasingly apparent. Leading the list of social maladies is prostitu- 
tion. Although local statistics are not available, the four tigers are said to have the highest concentration of prostitutes in Guangdong. In many town centres and along trunk roads, bars, night-clubs, "hair salons", massage parlours, "love hotels", and sauna baths abound, most of which supply women for "personal services". Passers-by are sometimes amazed by the bold approach of such operators. Around the entrances to hotels and discos, attractive young women, many from outside the province, plead to be taken on as companions. Observant pedestrians cannot fail to pick out discreet signs on lampposts and doorways that advertise cures for venereal diseases; nor can anyone miss the piles of pornographic materials sold in book shops and street corners.

The authorities are naturally concerned. Anti-vice campaigns are both regular and frequent. But with a thriving market of willing customers and sellers, prostitution and pornography remain a constant headache and embarrassment. Some cynics have even advanced the view that such evils are inevitable consequences of prosperity. The assumption is not only that such tastes have to be tolerated but also to be catered for. Allegedly, these lubicate business and "improve the investment environment". Some local officials have even openly discussed the feasibility of having "red light districts" under the guise of better mangement. In 1994, the brazen nature of the so-called "no prostitutes, no prosperity" theory (wu chang bu fu lun) prompted an angry rebuttal from Li Tieying, State Councillor responsible for cultural affairs. ${ }^{92}$ Moralists are equally shocked. Most local people remain resigned to the proliferation of such activities.

For law-abiding citizens, the major concern is crime. There are no data to ascertain the size of the problem. In private, local residents and drivers admit to being fearful of riding out-of-town coaches because of the alarming number of road robberies. The authorities are also worried about drug trafficking and abuse. Besides, gambling seems to be a new craze. On the bravado of local gamblers, a number of informants offer this vignette - bets that change hands are often not counted; instead stakes are gauged on the thickness of the banknotes. Reportedly, huge sums change hands in many a game. Big gamblers are also big spenders. Indeed, in the delta area, conspicuous consumption is readily visible. ${ }^{93}$ Consumerism and materialism are apparent 
everywhere. Local residents, while relishing their affluence, are rather anxious about the erosion of public morals. The general consensus is that the social health of the area has deteriorated alongside with, or even because of, prosperity. Most believe that the situation will get worse and that there is nothing much that the government can do.

\section{Conclusion}

All in all, the introduction of economic reform in post-Mao China has considerably improved the lot of the people. Concurrently it has also created great disparities and generated many social problems. The story of the Pearl River Delta is a good case in point. More than any other place in China, there the transition from planned to market economy is far advanced. Obviously, the process of modernisation is far from complete. One sign is that notwithstanding its stunning economic progress, social developments have scarcely kept pace. Attempts at social management have also been less than effective. In the delta area as well as in China as a whole, economic reform has enriched many citizens. Yet, it is doubtful whether reform has achieved the goal of common prosperity. The experience of the world suggests that economic advancement alone does not necessarily improve the quality of people's lives. What is more fundamental, development is not merely a matter of economic growth but the advancement of human well-being. Without social improvements, cultural enrichment and ideological enlightenment, there is no guarantee that people's lives can be really improved. Perhaps of the most relevance to the state is that when compatible policy reforms and institutional strategies fail to keep pace with rapid socio-economic change, social development will be far from balanced. Such lessons are important to China. At the present time the People's Republic of China is confronting many social, economic, and political problems closely related to imbalanced development. To the extent that these are allowed to gnaw at the fabric of society, social instability and moral decay will become the cost of growth. It may be risky to conclude that China, or the Pearl River Delta, has become a "risk society". But in order to save China from deteriorating into such a state, a lot needs to be done to ensure that real development, including social development, occur to improve the well-being of 1.2 billion people in the world. 


\section{NOTES}

1. U. Beck, Risk Society: Towards a New Modernity (London: Sage, 1992).

2. H. Harcuse, One Dimensional man (Boston: Beacon, 1964).

3. Han Sang-Jin, "A Rush-to Industralization and Its Pathological Consequences: The Theme of 'Risk Society' in Asian Context," paper presented at the 6th International Conference of Asian Sociology, November 2-5, 1995, Beijing.

4. U. Beck, "Risk Society: Outline of an Argument," paper presented at the International Sociological Association's World Congress, Bielefeld Germany, 1994, p. 2.

5. Beck, "Risk Society: Outline of an Argument."

6. J. Midgley, Social Development (London: SAGE Publications, 1995).

7. Ibid, p. 4.

8. For detailed discussion about social development, see, for example, C. Smith, Economic and Development, Growth and Welfare (London: Macmillan, 1994); Midgley, Social Development; S. MacPherson, "Social Policy in China in Contemporary Perspective," in L. Wong, and S. MacPherson, eds., Social Change and Social Policy in Contemporary China (Aldershot: Avebury, 1995).

9. Ibid.

10. J. Cheng and S. MacPherson, eds., Development in Southern China: A Report on Pearl River Delta Region Including the Special Economic Zones (Hong Kong: Longman, 1995).

11. Stastical Yearbook of China, 1995, p. 20, hereafter CSY.

12. The World Bank, From Plan to Market: World Development Report 1996 (Oxford: Oxford University Press, 1996), p. 21.

13. CYS 1995, pp. 24-25 and 35.

14. CSY 1995, pp. 20-21.

15. CSY 1995, p. 257.

16. World Bank, From Plan to Market, p. 19.

17. Jiang Liu, Lu Xueyi and Shan Tianlun, eds., 1995-1996 Nian Zhongguo: Shehui Xingshi Fenxi yu Yuce [China in 1995-1996: Analysis of Social Situation and Forecast] (Beijing: Zhongguo Shehui Kexue Chubanshe, 1996): 3-150.

18. L.A. Sklair, "The Cultural-Ideology of Consumerism in Urban China: Some Findings from a Survey in Shanghai," in R. Belk et al., cds., Consumption in Marketing Societies (Greenwich CT: JAL Press, 1995).

19. Sklair, ibid., W. Mahatoo, "Marketing in China," Journal of General Management, No. 15 (1990): 63-79; and S. Stewart, "Return of the Prodigals: The Overseas Chinese and Southern China's Economic Boom," in J. Khanna, ed., Natural Economic Territories and Challenge to the Nation-State (Washington: CSIS/ Westview Press, 1995).

20. J. Cha1, "Consumption and Living Standards in China," The China Quarterly, No. 131, 1992, pp. 721-49; T.W. Hu ct al., "Household Dur able Goods Ownership in Tianjin China," The China Quarterly, No. 120, 1989, pp. 787-99; and Sklair, "The Cultural-Ideology of Consumerism in Urban China." 
21. ZhuQingfang, "Renmin Shenghuo Wenbu Zhengzhang, Dan Wujia Shangzheng Tupo Jingjiexian," (People's Livelihood is Increasing Steadily but Price Rises have Exceeded the Warning Level), in Jiang Liu et al., eds., 1993-1994 Nian Zhongguo: ShehuiXingshi Fenxi Yu Yuce (China in 1993-1994; Analysis of Social Situation and Forecast) (Beijing: Zhongguo Shehui Kexue Chubanshe, 1994); and Jing Tihua et al., "Jingji Lanpishu: 1993-1994 Beijing Jingji Xingshi Fenxi yu Yuce" (Economic Blue Book: Beijing Economic Analysis and Forecast in 1993-1994) (Beijing: Shoudu Shifan Daxue Chubanshe, 1994).

22. H.B. Thoburn et al., "The Middle Class and the Market Place: The PRC, Overseas Chinese and Thailand," Advances in International Marketing, No. 1, 1989, pp. 143-78; and S. Rosen, "The Private Economy," Chinese Economic Studies XXI (Fall, 1987-88): 3-9 and (Winter, 1987-88): 3-7.

23. CSY 1995, p. 85.

24. J.L. Rocca, "The New Elites" in M. Brosseau and C.K. Lo, eds., China Review 1994 (Hong Kong: The Chinese University Press, 1994).

25. Wong Siu-lun, "Chinese Entrepreneurship and Economic Development" in J. Unger and B. McCormick, eds., China's Prospects: Lessons From Eastern Europe and East Asia (New York: M.E. Sharpe, 1996).

26. People's Daily, March 1, 1994.

27. Tsang Shu-Ki and Ma Yue, "An Open-Economy Macroeconometric Model of China: the Impacts of Foreign Capital," BRC P apers on China (Hong Kong: Schools of Business, Business Research Centre, Hong Kong Baptist University, 1995).

28. This comprises 3.3 million persons working in urban private enterprises, 12.3 million working in urban individual enterprises, 3.2 million working in rural private enterprises and 25.5 million working in rural individual enterprises, CSY 1995, p. 85.

29. X. Li and L. Liu, eds., Shei Zhu Fou Chen (Who Control the Ups and Downs) (Beijing: Tuanjie Chubanshe, 1993); S.G. Kong, ed., Shanghai Zhuliu (Polluted Water in the Commercial Sea) (Beijing: Tuanjie Chubanshe, 1993); K.H. Mok, "Prosperity Without Equality: An Examination of the Socio-Political Impacts of Structural Modification of Post-Mao Society," in Wong and MacPherson, Social Change and Social Policy in Contemporary China.

30. Wu Jingliang, cited in G. Xiao and H.Y. Gao, "The Engine of Growth and the Root of Inflation in the Chinese Economy?" in M. Brosseau and C.K. Lo, eds., China Review 1994 (Hong Kong: The Chinese University Press, 1994), p. 9.2.

31. Chao Chu-shan, "Pcking's Policy of Opening Up to the Outside World," Issues and Studies, No. 12, 1994, pp. 22-44.

32. Xiao and Gao, "The Engine of Growth and the Root of Inflation in the Chinese Economy?"

33. M. Anderson, Madison Avenue in Asia: Politics and Transnational Advertising (Ratherford N.J. : Farleigh-Dickinson University Press, 1984).

34. R. Stross, "The Return of Advertising in China: A Survey of the Ideological Reversal," The China Quarterly, No. 123, 1990, pp. 485-502.

35. Scc, for example, Sklair, "The Cultural-Ideology of Consumerism in Urban 
China," J. Lull and S.W. Sun, "Agent of Modernization; Television and Urban Chinese Families," in J. Lull, eds., World Families Watch Television (Newbury Park: SAGE Publication, 1988); M. Rice and Lu Zaiming, "A Content Analysis of Chinese Magazine Advertisements," Journal of Advertising, No. 4, 1988, pp. 4348; O. Schell, "Serving the People with Advertising," Whole Earth Review, Spring 1987, pp. 88-93; O. Schell, Discos and Democracy (New York: Anchor Books Doubleday, 1988).

36. H.Q. Huang et al., Economic Development of the Pearl River Delta: A Retrospect and Prospects (Guangzhou: Research Centre of Pearl River Delta Economic Development and Management, Zhongshan University, 1992).

37. Sklair, "The Cultural-Ideology of Consumerism in Urban China."

38. M.K. L1 and J.T. Li, eds., Zhongguo Shehui Fenceng (Social Stratification in China) (Hong Kong: The Commercial Press, 1994).

39. Mok, "Prosperity Without Equality."

40. Li Qiang, "Occupational Structure of Contemporary Mainland China," The Journal of East and West Studies 23 (2, November 1994): 37-57.

41. Yan Yunxiang, "Dislocation, Reposition and Restratification: Structural Changes in Chinese Society," in Brosseau and Lo, China Review 1994; 1 a Kung Pao, January 12, 1994.

42. R. Chan, "The Urban Migrants - The Challenge to Public Policy," in Wong and MacPherson, Social Change and Social Policy in Contemporary China; L. Wong, "China's Urban Migrants - The Public Policy Challenge," Pacific Affairs 3 (1994): 335-55.

43. Renmin Ribao, October 2, 1995.

44. Hong Kong Economic Journal, February 15, 1996.

45. Ibid.

46. CSY 1995 , p. 85.

47. See, for example, M. Weber, Basic Concepts in Sociology (New York: Philosophical Library, Inc., 1962); R. Breen and D. Rothman, Class Stratification: A Comparative Perspective (London: Harvester Wheatsheaf, 1995).

48. Hirschman suggests that people with different socio-economic and political opportunities may have different responses to external forces or pressure. Accordingly, people may choose "exit", "voice" or "loyalty" approaches in response to their unique circumstances. With enhanced financial ability to eschew dependence from the state, people in the mainland nowadays have far more alternatives in responding to their circumstances. See, A Hirschman, Exit, Voice and Loyalty: Responses to Decline in firms, Organizations and States (Cambridge, Mass: Harvard University Press, 1970).

49. Hua Sheng, Zhang Xiejun, and Lo Xiaopeng, "After 'Ten Years' Reform in China: Retrospective, Reflection and Future Looking," Research in Economics, Part I, No. 8 and Part II, No. 11, 1988; Lin Jing, The Red Guard's Path to Violence: Political, Educational, and Psychological Factors (New York, Praeger, 1991); Lin Jing, The Opening of the Chinese Mind (Connecticut, Praeger: Westport, 1994).

50. Lin Jing, "Democracy, Modernization, and Education: China in Transition," paper presented at the International Symposium on Education and Social-Political Transitions in Asia, May 29-31, 1995, the University of Hong Kong, p. 5. 
51. Li Jiangtao, "Danwei zai Shchui Fenceng zhong de Yiyi" (Work Units: The Implications for Social Stratıfication) in S.K. Lau et al., Inequalties and Development: Social Stratification in Chinese Societies (Hong Kong: The Chinese University Press, 1994); D. Goodman, "New Economic Elites," in R. Benewick and P. Wingrove, eds., China in the 1990s (London: Macmillan, 1995).

52. Yan, "Dislocation, Reposition and Restratification," pp. 15.19-15.20.

53. Ibid.

54. S. Rosen, "Students and the State in China: The Crisis in Ideology and Organization," in A.L. Rosenbaum, ed., State and Society in China: The Consequence of Reform (Boulder: Westview Press, 1992).

55. A. Liu, "Communications and Development in Post-Mao Mainland China," Issue and Studies 12 (1991): 73-99. Similary, Howell also categorises these voluntarily organised social associations into four typologies, namely, (1) old, official social organisations; (2) semi-officials social organisations; (3) new popular social organisations and (4) illegal organisations. No matter how different these classifications are, social organisations and associations have come into more prominence in post-Mao China. See J. Howell, "Civil Society," in Benewick and Wingrove, China in the 1990s.

56. Liu, "Communications and Development in Post-Mao Mainland China," p. 82. 57. David S.G. Goodman and B. Hooper, eds., China's Quiet Revolution: New Interactions Between State and Society (Murdoch: Longman Cheshire, 1994); J. Howcll, "Refashioning State-Society Relations in China," European Journal of Development Research 6 (1, June 1994): 197-215.

58. Ibid.

59. L. Sullivan, "The Emergence of Civil Society in China, Spring 1989," in R.V. DesForges et al., eds., China: The Crisis of 1989 Origins and Implications, Vol. I, Council I on International Studies and Programs, Special Studies, No. 158 (Buffalo: State University of New York, 1990).

60. K.H. Mok, "A Renegotiation of the Private/Public Distribution: The Emergence of Private Education and the Quest for Professional Autonomy in the Pearl River Delta," paper presented at the 47th Annual Meeting of Association of Asian Studies, April 11-17, 1996, Honolulu, Hawaii.

61. L. Wong and K.H. Mok, "The Reform and the Changing Social Context," in Wong and MacPherson, Social Change and Social Policy in Contemporary China; G.C. Chu and Ju Yannan, The Great Wall in Ruins (Albany: State University of New York Press, 1994).

62. Liao Yi, "Changing in Social Values and Educational Influence in Guangdong Province," paper presented at the International Symposium on Education and Social-Political Transitions in Asia, May 29-31, 1995, the University of Hong Kong. 63. D. Kelly, "Chinese Marxism Since Tiananmen: Between Evaporation and Dismemberment," in D. Goodman and G. Segal, eds., China in the Nineties: Crisis Management and Beyond (Oxford: Clarendon Press, 1991); G. White, "The End of Ideocracy," in Benewick and Wingrove, China in the 1990s.

64. Rosen, "Students and the State in China," p. 174. 
65. Min Qi, Zhongguo Zhengzhi Wenhua: Minzhu Zhengzhi Nanchande Shehui Xinli Yinsu (Chinese Political Culture: The Social Psychological Elements that Make it Difficult to Produce Democratic Politics) (Kunming: Yunnan Renmin Chubanshe, 1989), p. 123; M. Goldman et al., "China's Intellec tuals in the Deng Era: Loss of Identity with the State," in L. Ditter and S.S. Kim, eds., China's Quest for National Identity (Ithaca and London: Cornell University Press, 1993).

66. Zhi Ming and Lian Xuehua, "Daxuesheng de Jiben Zhuyi Guandian" (The Basic Political Views of University Students), Nanfang Qingshaonian Yanjiu (Studies on Teenagers in the South), No. 1, 1988, p. 420.

67. Quan Singlian, "An Investigation and Analysis of the Ideological and Political Education of University Students in Beijing," Qingnian Yanjiu (Youth Research), No. 3, 1990, pp. 15-18; Rosen, "Students and the State in China."

68. Zheng Yongnian, "Development and Democracy: Are They Compatible in China?", Political Science Quarterly 2 (1994): 235-95.

69. X.G. Zhou, The State and Civil Society Relationship in Contemporary China (Taipei: Kwaikuan Chubanshe, 1992).

70. China Information, Vol. VI (1, 1989), p. 98.

71. Li Qiang, "Social Mobility in Post-Mao China: Some Implications," paper presented to the Department of Applied Social Studies, April 28, 1995, at the City University of Hong Kong.

72. He Baogang, "The Idea of Civil Society in Mainland and Taiwan, 1986-92," Issues and Studies 6 (1995): 24-65.

73. Goldman et al, "China's Intellectuals in the Deng Era"; M. Bonnin and Y. Chervier, "The Intellectual and the State: Social Dynamics of Autonomy during the Post-Mao Era," The China Quarterly 123 (1991): 569-93; K.H. Mok, Intellectuals and State in Post-Mao China, (London: Macmillan, 1997 forthcoming).

74. Mok, "A Renegotiation of the Private/Public Distribution."

75. Renmin Ribao, July 9, 1987; Wen Hui Bao, October 16, 1988.

76. C.C.Chiang, "The Social Aftermaths of Mainland China's Economic Reform," Issues and Studies 2 (1989): 39.

77. J.J.Qian, "On Prices, Education and Social Conductor," Central Daily, October $13,1988$.

78. Zhou Fangliang, ed., ZhiShi Fenzi Jingji Zhengce Yanjiu: Kunjing Yu Chulu (Research on Chinese Intellectuals' Economic Condition: Constraints and Prospects) (Beijing: Chunqiu Chubanshe, 1989); Zhu, "Renmin Shenghuo Wenbu Zhengzhang."

79. Chiang, "The Social Aftermaths of Mainland China's Economic Reform," p. 41.

80. L. Wong, "Welfare and Affluence in the Pearl River Delta," in Cheng and MacPherson, Development in Southern China.

81. Guangdong Tongji Nianjian, 1995.

82. Ibid.

83. E. Vogel, One Step Ahead in China: Guangdong Under Reform (Mass, Cambridge: Harvard University Press, 1989).

84. C. Chiu, "The Reform Strategies of the Four Little Tigers of Guangdong: 
Dongguan, Nanhai, Shunde and Zhongshan," in Cheng and MacPherson, Development in Southern China.

85. Ming Pao, October 20, 1994.

86. Renmin Ribao, October 2, 1995.

87. Li Ruojian,"Nanzhongguo DiquLaodongli Shichang Zhuangkuang yuZhujiang Sanjiaozhou Laodongli Shichang de Fazhan" (The State of the South China Labour Market and the Development of the Pearl River Delta Labour Market) (Guangzhou: Zhongshan University, 1993).

88. Wide Angle, August 1993, pp. 24-27: G. Wang, "Foreign Investment Law in the Pearl River Delta," in Cheng and MacPherson, Development in Southern China. 89. Ming Pao, January 8, 1994; Time Magazine, June 27, 1994, pp. 14-18; Wide Angle, August 1993, pp. 24-27.

90. Ming Pao, November 20, 1993, November 21, 1993, December 8, 1993, January 1, 1994; South China Morning Post, November 20, 1993.

91. Hong Kong Economic Journal, August 30, 1994.

92. Ming Pao, January 9, 1994.

93. Huang et al., Economic Development of the Pearl River Delta.

Linda Wong is Associate Professor and Ka-ho Mok is Assistant Professor in the Department of Public and Social Administration at the City University of Hong Kong. 